\title{
Design of a MPPT controller for permanent magnet synchronous generator driven wind turbine
}

\author{
Truong Viet Anh ${ }^{1, *}$, Huynh Quang Minh², Vo Hoai Thuong ${ }^{3}$
}

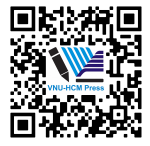

Use your smartphone to scan this QR code and download this article

${ }^{1}$ HCMC University of Technology and Education, Vietnam

${ }^{2}$ University of Technology, VNU-HCM, Vietnam

${ }^{3}$ Tien Giang Vocational College, Vietnam

Correspondence

Truong Viet Anh, HCMC University of Technology and Education, Vietnam

Email: anhtv@hcmute.edu.vn

History

- Received: 08-01-2019

- Accepted: 28-9-2019

- Published: 28-12-2019

DOI :10.32508/stdjet.v2i4.440

\section{Check for updates}

\section{Copyright}

( ) VNU-HCM Press. This is an openaccess article distributed under the terms of the Creative Commons Attribution 4.0 International license.

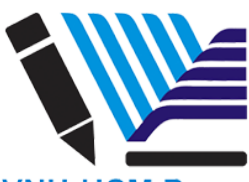

ABSTRACT

Wind and other renewable energies are more and more developed all over the world, especially in countries with high wind potential such as Vietnam, to replace fossil energy, which would be exhausted in the near future. One important characteristic of wind turbines is that at each different wind speed, there exists a working point, represented by the rotation speed and the mechanical power at the crankshaft of the wind turbine, at which the maximum mechanical power is obtained, called maximum power point (MPP). Therefore, when the wind speed changes, this working point must be changed to be able to extract the maximum power from the wind to improve the total efficiency of the wind turbine system. This, in a wind energy conversion system (WECS), is assigned to the maximum power point tracking (MPPT) controller. In this paper, a MPPT controller is proposed, based on an improved Perturb and Observe $(\mathrm{P \& O})$ algorithm, for wind turbines using permanent magnet synchronous generator (PMSG), to maximize energy without measuring the wind speed and power characteristics of the wind turbine. An experimental model is also designed and tested in laboratory conditions, in which two coefficients $K_{1}$ and $K_{2}$ are used in turn when the working point is far or close to the maximum power point. The experimental results show that the proposed MPPT controller allows the extraction of maximum power from wind turbines under variable wind speed without determining the wind speed and characteristics of the wind turbine system.

Key words: wind turbine, permanent magnet synchronous generator, maximum power point tracking, perturb and observe, AC/DC converter, DC/DC converter

\section{INTRODUCTION}

In recent years, the use of renewable energy resources is more and more increased due to the increasing need for energy and the shortage of traditional energy sources in the near future ${ }^{1}$.

The literature review shows that, renewable energy systems are not cost competitive against conventional fossil fuel power systems. However, the need for cleaner power and improvements in alternative energy technologies gives good potential for widespread use of such systems.

Community facilities such as rural hospitals, schools, telecommunication and water pumping stations can contribute significantly to the welfare of people and rural development. Renewable energy systems have demonstrated the potential to provide support in some of the basic infrastructure needs in remote and urban areas. One of the interesting utilizations of the renewable energy in community development is to electrify remote villages and rural areas located so far from power stations and distribution networks which are uneconomical to install. Recent research and development in renewable energy sources have shown excellent potential, as a form of supplementary contribution to conventional power generation systems. In order to meet sustained load demands during varying natural conditions, different energy sources and converters need to be integrated with each other for extended usage of alternative energy. Therefore, it is necessary to construct a system capable of generating maximum power under these constraints ${ }^{2}$.

The wind energy conversion system (WECS) incorporated in the proposed scheme consists of a wind turbine coupled to a permanent magnet synchronous generator (PMSG). An AC/DC power electronic interface with diode bridge rectifier and a DC/DC boost converter are used for maximum power tracking. An improved $\mathrm{P} \& \mathrm{O}$ method is proposed to avoid the instable effect of original one ${ }^{3}$.

There are two types of MPPT controller for wind turbine: indirect and direct. Indirect MPPT controllers are based on the knowledge of the generator's power characteristic, which is usually not available with a high degree of accuracy and also changes with rotor aging and require wind speed measurement ${ }^{4}$. On the other hand, direct MPPT controllers are independent from the knowledge of the generator curve, and 
the operating point is independent of climatic conditions ${ }^{5}$. In this paper, a direct MPPT controller for variable speed PMSG driven wind turbine is proposed and tested in laboratory condition to extract maximum power from the wind without any knowledge about generator's characteristic or load condition.

\section{APPROACH}

\section{Wind aerodynamics}

Mechanic power of a wind turbine can be expressed in terms of the air density $\rho$, the blade radius $R_{\text {blade }}$, and is the wind speed $v_{\text {wind }}{ }^{6}$ :

$$
P_{m}=0.5 C_{p} \rho \pi R_{b h d e}^{2} v_{\text {wind }}^{3}
$$

where $C_{p}$ is the power coefficient. This coefficient is also known as Betz limit. It can be expressed in terms of reduced velocity $\lambda$ and blade angle $\beta$. If $\omega$ is the rotor speed, the reduced speed $\lambda$ is defined:

$$
\lambda=\omega R_{\text {blade }} / V_{\text {wind }}
$$

A generic equation is used to model the power coefficient $C_{p}=C_{p}(\lambda, \beta)$, based on the modeling turbine characteristics described in ${ }^{7}$ :

$$
C_{p}(\lambda, \beta)=0.5\left(98 / \lambda_{i}-0.4 \beta-5\right) e^{-16.5 \lambda_{i}}
$$

where:

$$
\lambda_{i}=1 /\left[1 /(\lambda+0.08 \beta)-0.035 /\left(\beta^{3}+1\right)\right]
$$

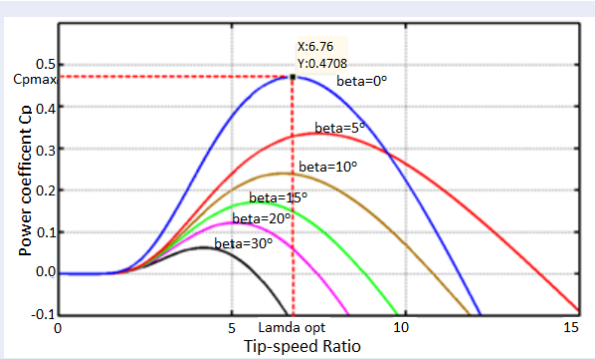

Figure 1: $C_{p}$ vs. $\lambda$, for various pitch angles $\beta$.

The characteristic function $C_{p}$ vs. $\lambda$, for various values of the pitch angle $\beta$, is illustrated in Figure 1. The maximum value of $C_{p}$ is achieved for $\beta=0^{\circ}$. This particular value $\lambda_{\text {opt }}$ results in the point of optimal efficiency where the wind turbine captures the maximum power $^{8}$. In this work, with laboratory condition, the tested wind turbine does not have the pitch controller system, so we considered that $\beta=0^{\circ}$ at all times.

If the speed ratio is maintained at its optimal value $\lambda_{\text {opt }}$, the power coefficient is at its maximum value
$C_{p M}=C_{p}\left(\lambda_{o p t}\right)$, the maximum power extracted from the wind turbine will be:

$$
P_{m_{-} o p t}=0.5 C_{p M} \rho \pi R_{\text {blade }}^{2} V_{\text {wind }}^{3}
$$

On the other hand, the speed ratio assumed to be maintained at the optimum value, we obtain the optimum speed rotor:

$$
\begin{aligned}
& \lambda_{\text {opt }}=\left(\omega_{\text {opt }} R_{\text {blade }}\right) / \nu_{\text {wind }} \\
& \rightarrow \omega_{\text {opt }}=\left(\lambda_{\text {opt }} V_{\text {wind }}\right) / R_{\text {blade }}
\end{aligned}
$$

Thus, for each wind speed $v_{\text {wind }}$, there is an optimal rotor speed $\omega_{\text {opt }}$ which made a maximum power recovered from the wind (Figure 2$)^{9}$.

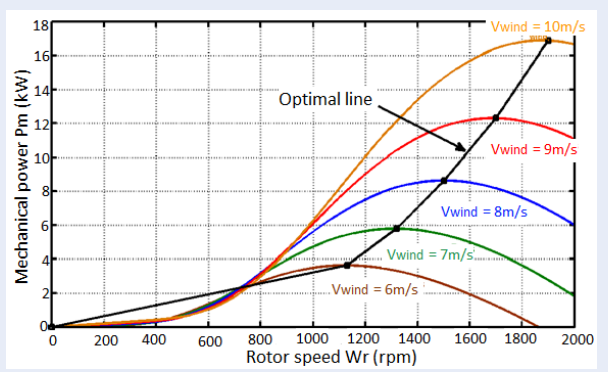

Figure 2: Mechanic power vs. rotor speed.

\section{Electrical system modeling}

The WECS incorporated in our scheme consists of a wind turbine coupled to a PMSG. Since the PMSG produces variable amplitude - variable frequency voltage, additional power electronic devices are required to meet power quality demand. A three-phase diode bridge rectifier is used for the AC/DC conversion. A boost converter (DC/DC) is used to vary the rotor speed by adjusting the converter's duty cycle (Figure 3).

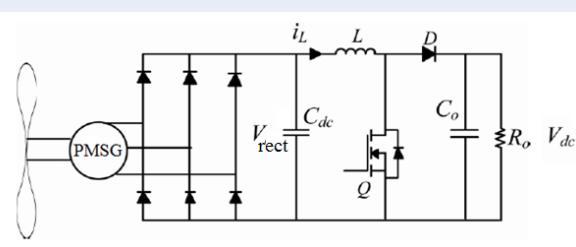

Figure 3: PMSG driven wind turbine configuration.

The dynamic model of PMSG can be represented in the Park's system using these equations ${ }^{10}$ :

$$
V_{d}=-R_{s} i_{d}-L_{d} d i_{d} / d t+\omega L_{q} i_{q}
$$




$$
V_{q}=-R_{s} i_{q}-L_{q} d i_{q} / d t-\omega L_{d} i_{d}+\omega \lambda_{m}
$$

The expression of electromagnetic torque in the rotor is given by:

$$
\begin{gathered}
T_{e}=3 / 2 p\left[\left(L_{d}-L_{q}\right) i_{q} i_{d}-\lambda_{m} i_{q}\right] \\
\omega_{e}=\omega \cdot R
\end{gathered}
$$

where $p$ is the number of pole pair, $\lambda_{m}$ is the magnetic flux, $L_{d}$ is the direct axis inductance, $L_{q}$ is the inductance in quadrature, $R_{S}$ is the stator resistance and $\omega$ is the electrical angular frequency.

If the rotor is cylindrical, $L_{d} \approx L_{q} \approx L_{s}$ so:

$$
T_{e}=-1.5 p i_{q} \lambda_{m}
$$

Relationship between mechanical torque and electromagnetic torque in a wind turbine:

$$
T_{m}-T_{e}=J \cdot d \omega / d t
$$

where $J$ is the inertia of the wind turbine.

In PMSG wind generation systems, the output current and voltage are proportional to the electromagnetic torque and rotor speed, respectively ${ }^{9}$ :

$$
\begin{gathered}
T_{e}=k_{T} I_{a} \\
E=k_{e} \omega
\end{gathered}
$$

Where $I_{a}$ is the stator current. On the other hand:

$$
E^{2}=V_{W T}^{2}+\left(I_{a} L_{s} \omega\right)^{2}
$$

$V_{W T}$ is the generator phase voltage and $L_{S}$ is the inductance of the generator.

From (14), (15) we have:

$$
\omega \propto V_{W T} \rightarrow d \omega / d t \propto d V_{W P} / d t
$$

Thus, in a variable speed PMSG driven wind turbine, we can vary the output voltage $V_{W T}$ of the generator (by adjusting the duty cycle of the boots converter) to change the rotor speed $\omega$. If we can control our system to work at the optimal rotor speed $\omega_{o p t}$, maximum power will be extracted from the wind turbine.

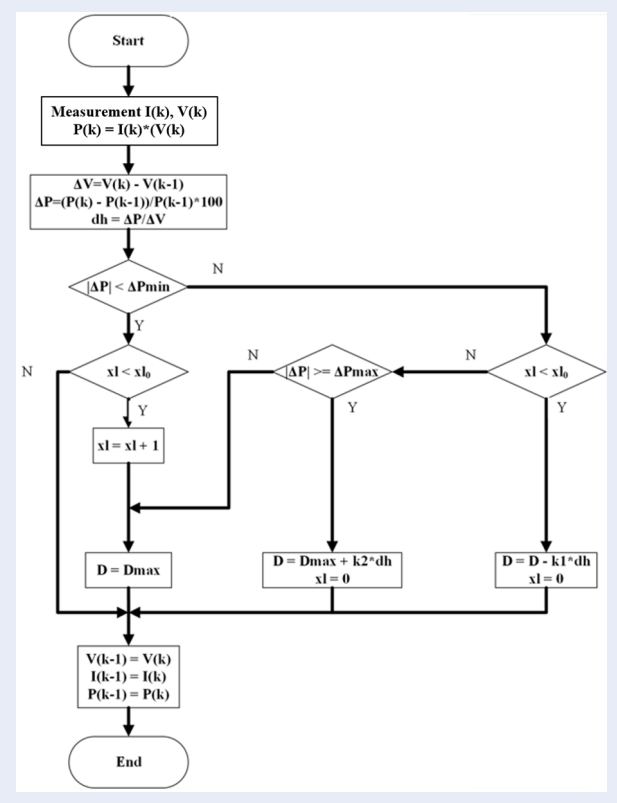

Figure 4: Proposed algorithm.

\section{PROPOSED ALGORITHM}

\section{Conventional P\&O MPPT controller}

In the field of MPPT for wind energy, the $\mathrm{P} \& \mathrm{O}$ algorithm is a very popular method because of its simplicity and easy implementation. The main idea is the perturbation of rotor speed and takes reaction to reach the MPP. If the variation of the rotor speed increases the power extracted, the next variation will be kept in that direction. Conversely, if the variation of the rotor speed decreases the power extracted, the next variation will be reversed ${ }^{10}$.

However, this method has its own negative points. The response to wind speed change is extremely slow, especially for large inertia wind turbines ${ }^{11,12}$. Rapidly fluctuating character of wind supply makes the situation even worse. Oscillation around the MPP is also another inevitable disadvantage. All these drawbacks can significantly lower MPPT efficiency and may cause oscillation in the system ${ }^{13,14}$.

\section{Proposed MPPT controller}

The proposed algorithm is based on the basic principles of the $\mathrm{P} \& \mathrm{O}$ algorithm, by adapting the value of perturbation step to achieve the faster convergence rate. Variation of the next step is proportional with the derivative of power and voltage $\left(\Delta \mathrm{D}=\mathrm{k}^{\star} \Delta \mathrm{P} / \Delta \mathrm{V}\right)$. Around the maximum point, when $\Delta \mathrm{P}$ varies near zero, we will stop the perturbation. In addition, when the wind speed varies, based on the rise in current or 
voltage, we can predict the new position of the MPP. That means, when wind speed increase, the new MPP will move to the left of the power curve, and when wind speed decrease, the new MPP will move to the right.

The flow chart of the proposed algorithm is given in Figure 4. This algorithm needs to determine the two experimental constant $\mathrm{k}_{1}$ and $\mathrm{k}_{2}$. When the operating point is far away from MPP, we should use a big variation to reach the MPP more quickly. When our system is working in the MPP and wind speed change, we will use smaller variation to keep the system stable. Thus $\mathrm{k}_{1}>\mathrm{k}_{2}$ and their value are proportional to the turbine capacity. The $\mathrm{k}_{1}$ and $\mathrm{k}_{2}$ are determined experimentally on physical model shown in Figure 5. The experimental parameters of our proposed controller are given in Table 1 .

Table 1: Experimental parameters

\begin{tabular}{cc}
\hline Parameter & Value \\
$\Delta \mathrm{P}_{\min }$ & 0.4 \\
$\Delta \mathrm{P}_{\max }$ & 1.7 \\
$\mathrm{xl}_{0}$ & 10 \\
$\mathrm{k}_{1}$ & 0.7 \\
$\mathrm{k}_{2}$ & 0.35 \\
\hline
\end{tabular}

\section{EXPERIMENTAL, RESULTS AND DISCUSSION}

\section{Tested system}

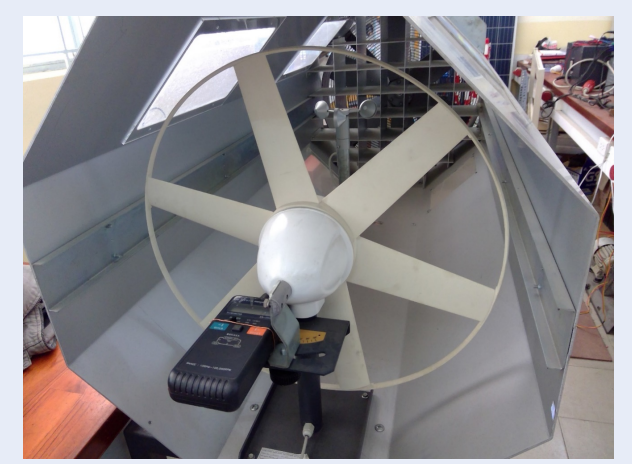

Figure 5: The wind turbine emulator.

The wind turbine emulator includes a tunnel and a three-phase motor controlled by an inverter, a wind speed gauge, a 6-bladed turbine system and a PMSG. The wind speed is varied by changing the three-phase

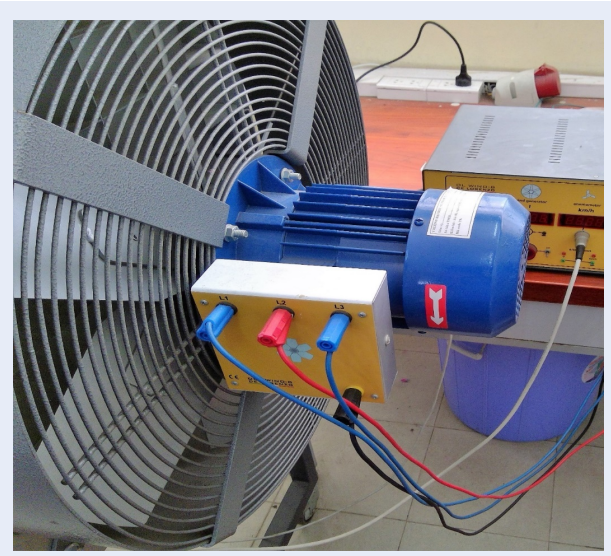

Figure 6: The three-phase motor for wind speed simulator.

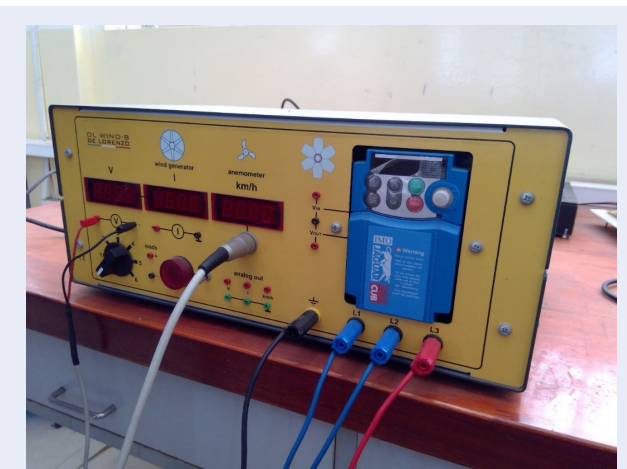

Figure 7: Controller for wind speed simulator.

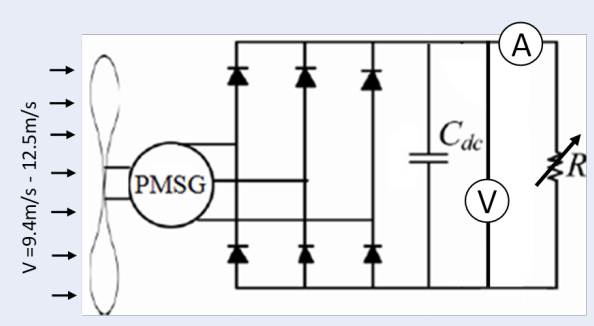

(A)

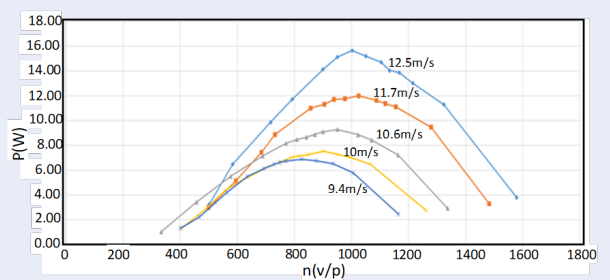

(B)

Figure 8: a) Measured power-speed curves. b) Power according to wind speed and load. 
motor speed through the inverter. The output voltage is rectified by a three-phase diode bridge. These devices were produced by the DE LORENZO group (Italy) in Figures 5, 6 and 7.

To determine the maximum power point for each wind speed of a wind turbine system, an experiment is arranged as shown in Figure 8a and the results are shown in Figure $8 b$.

\section{Results and discussion}

At $12.5 \mathrm{~m} / \mathrm{s}$ wind speed, we tested our system in 2 conditions: without MPPT controller (Figures 9 and 11) and with MPPT controller (Figures 10 and 12). We also use a battery and then a $60 \mathrm{~W}-220 \mathrm{~V}$ lamp as load, we obtained the following result:

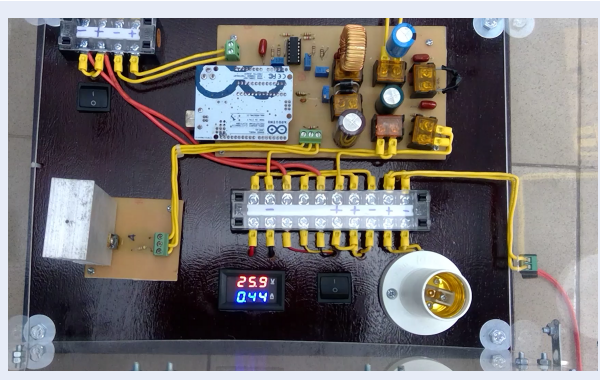

Figure 9: Results without MPPT controller at $\mathbf{1 2 . 5}$ $\mathrm{m} / \mathrm{s}$ wind speed with battery load.

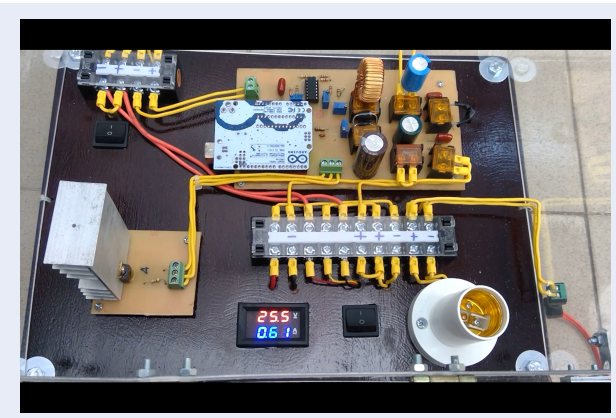

Figure 10: Results with MPPT controller at $\mathbf{1 2 . 5}$ $\mathrm{m} / \mathrm{s}$ wind speed with battery load.

With the battery load, when the MPPT is not activated, the charging power is $11.4 \mathrm{~W}$, and when the MPPT controller is activated, the charging capacity reaches $15.6 \mathrm{~W}$. With the $60 \mathrm{~W}-220 \mathrm{~V}$ lamp loading without MPPT system, the measured power is $3.9 \mathrm{~W}$, after activating the MPPT controller the measured power is now $15.6 \mathrm{~W}$.

Results obtained at different wind speeds with $60 \mathrm{~W}$ $220 \mathrm{~V}$ are given in Table 2.

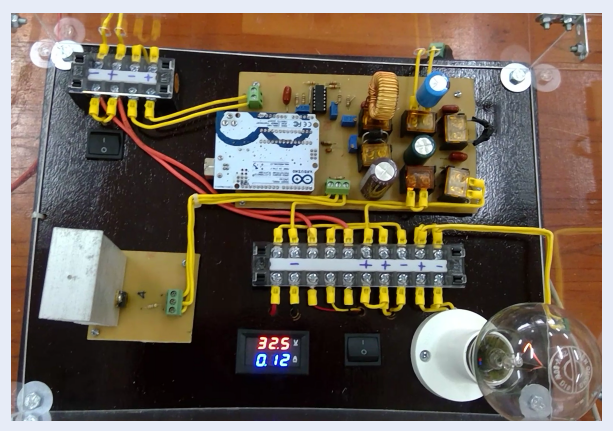

Figure 11: Results without MPPT controller at $12.5 \mathrm{~m} / \mathrm{s}$ wind speed with $60 \mathrm{~W}-220 \mathrm{~V}$ lamp load.

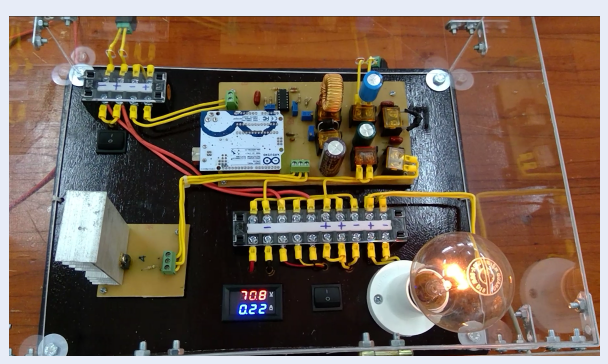

Figure 12: Results without MPPT controller at $12.5 \mathrm{~m} / \mathrm{s}$ wind speed with $60 \mathrm{~W}-220 \mathrm{~V}$ lamp load.

Table 2 shows the maximum power supplied by the MPPT unit for lamps similar to the resistor survey results in Figure 8. We can see that with our proposed MPPT controller, when wind speed and load change, the power extracted from our WECS is always maximized.

Table 3 presents the comparison of the time to reach the MPP when experimenting for wind speed from $0 \mathrm{~m} / \mathrm{s}$ to $10 \mathrm{~m} / \mathrm{s}$, then down to $8 \mathrm{~m} / \mathrm{s}$ and then up to $10 \mathrm{~m} / \mathrm{s}$.

Table 3: Compare the time to get the maximum power

\begin{tabular}{cccc}
\hline & \multicolumn{3}{c}{ Time to get maximum power } \\
$\mathrm{V}(\mathrm{m} / \mathrm{s})$ & $0 \rightarrow 10$ & $10 \rightarrow 8$ & $8 \rightarrow 10$ \\
14 & $20 \mathrm{~s}$ & $7 \mathrm{~s}-8 \mathrm{~s}$ & $13 \mathrm{~s}-14 \mathrm{~s}$ \\
$\begin{array}{c}\text { Proposed } \\
\text { algorithm }\end{array}$ & $12 \mathrm{~s}$ & $7 \mathrm{~s}-8 \mathrm{~s}$ & $7 \mathrm{~s}-8 \mathrm{~s}$ \\
\hline
\end{tabular}

The $\mathrm{P} \& \mathrm{O}$ algorithm of Badreddine et al. ${ }^{14}$ takes more than 20 seconds to achieve MPP while the proposed algorithm only needs 12 seconds in the inception phase. When the wind speed increases from $8 \mathrm{~m} / \mathrm{s}$ to $10 \mathrm{~m} / \mathrm{s}$, the time to get the MPP of the proposed algorithm is also faster than that in Badreddine et al. ${ }^{14}$. 
Table 2: Summary of experimental results

\begin{tabular}{cccccccc}
\hline $\begin{array}{c}\text { Wind } \\
(\mathbf{m} / \mathbf{s})\end{array}$ & & Without MPPT & & & With MPPT & & $\begin{array}{c}\text { P }_{\max }(\mathbf{W}) \text { at } \\
\text { Figure } 8\end{array}$ \\
& $\mathbf{U}(\mathbf{V})$ & $\mathbf{I}(\mathbf{A})$ & $\mathbf{P}(\mathbf{W})$ & $\mathbf{U}(\mathbf{V})$ & $\mathbf{I}(\mathbf{A})$ & $\mathbf{P}(\mathbf{W})$ & \\
9.4 & 22.4 & 0.11 & 2.46 & 49.0 & 0.15 & $\mathbf{6 . 8 6}$ & $\mathbf{6 . 8 8}$ \\
10.0 & 24.9 & 0.11 & 2.74 & 53.0 & 0.14 & $\mathbf{7 . 4 2}$ & $\mathbf{7 . 5 2}$ \\
10.6 & 26.5 & 0.11 & 2.92 & 61.0 & 0.15 & $\mathbf{9 . 1 5}$ & $\mathbf{9 . 2 8}$ \\
11.7 & 29.9 & 0.11 & 3.29 & 75.0 & 0.16 & $\mathbf{1 2 . 0}$ & $\mathbf{1 2 . 0 0}$ \\
12.5 & 32.5 & 0.12 & 3.90 & 70.8 & 0.22 & $\mathbf{1 5 . 6}$ & $\mathbf{1 5 . 6 6}$ \\
\hline
\end{tabular}

\section{CONCLUSION}

In this paper, an adaptive perturbation MPPT controller for WECS is designed and tested in laboratory condition. Without information of wind speed, generator's power characteristic or load condition, control signals were generated to extract maximum power from the wind. Experimental results show that our proposed controller works well to achieve the MPP of the wind turbine system at various wind speeds and load conditions.

\section{ABBREVIATION}

MPP: maximum power point

WECS: wind energy conversion system

MPPT: maximum power point tracking

P\&O: Perturb and Observe

PMSG: permanent magnet synchronous generator

AC: alternating current

DC: direct current

\section{CONFLICT OF INTEREST}

In this paper, there is no conflict of interest.

\section{AUTHORS' CONTRIBUTION}

Truong Viet Anh, Vo Hoai Thuong have contributed in conducting experiments. Huynh Quang Minh has tested experiments. Truong Viet Anh, Huynh Quang Minh wrote the manuscript.

\section{REFERENCES}

1. Abdullah MA, Yatim AHM, Tan CW, Saidur R. A review of maximum power point tracking algorithms for wind energy systems. Renewable and Sustainable Energy Reviews. 2012;16:3220-3227.

2. Trinh QN, Lee HH. Fuzzy logic controller for maximum power tracking in PMSG-based wind power systems. Advanced Intelligent Computing Theories and Applications with Aspects of Artificial Intelligence. 2010;p. 543-553.

3. Koutroulis E, Kalaitzakis K. Design of a maximum power tracking system for wind-energy-conversion applications. IEEE Transactions on Industrial Electronics. April 2006;53(2):486494.
4. Melício R, Mendes VMF, Catalão JPS. A Pitch Control Malfunction Analysis for Wind Turbines with Permanent Magnet Synchronous Generator and Full-power Converters: Proportional Integral Versus Fractional-order Controllers. Electric Power Compoments and Systems. 2010;38(4):387-406.

5. Memije D, Rodríguez JJ, Carranza O, Ortega R. Improving the performance of MPPT in a wind generation system using a wind speed estimation by Newton Raphson. IEEE International Autumn Meeting on Power, Electronics and Computing (ROPEC). 2016;

6. Zou Y, He J. Comprehensive modeling, simulation and experimental validation of Permanent Magnet Synchronous generator wind power system. IEEE/IAS 52nd Industrial and Commercial Power Systems Technical Conference (I\&CPS). 2016;

7. Saad L, Hicham H, Khalid F. Optimal tracking, modeling and control of aerogenerator based on PMSG driven by wind turbine. IEEE International Conference on Renewable Energy Research and Applications (ICRERA). 2016;.

8. Linus RM, Damodharan P. Maximum power point tracking method using a modified perturb and observe algorithm for grid connected wind energy conversion systems. IET Renewable Power Generation. 2015;9(6):682-689.

9. Huynh Q, Nollet F, Essounbouli N, Hamzaoui A. Fuzzy control of variable speed wind turbine using permanent magnet synchronous machine for stand-alone system. In: Sustainability in Energy and Buildings: Proceedings of the 3rd International Conference in Sustainability in Energy and Buildings (SEB 11). vol. 12. Springer Verlag; 2012. p. 31.

10. Li L, Han B, Ren Y, Brindley J, Jiang L. An improved hybrid hill climb searching control for MPPT of wind power generation systems under fast varying wind speed. International Conference on Renewable Power Generation. 2015;p. 1-6.

11. Nayanar V, Kumaresan N, Gounden NA. A Single-SensorBased MPPT Controller for Wind-Driven Induction Generators Supplying DC Microgrid. IEEE Transactions on Power Electronics. Feb 2016;31(2):1161-1172.

12. Yang Z, Yin M, Xu Y, Zhang Z, Zou Y, Dong ZY. A Multi-Point Method Considering the Maximum Power Point Tracking Dynamic Process for Aerodynamic Optimization of VariableSpeed Wind Turbine Blades. Energies. May 2016;9(6):425.

13. Lan F, Tao L, Li J, Yao Z. An improved variable step hill-climbing searching algorithm for tracking maximum power point of wind power system. China International Conference on Electricity Distribution (CICED). Aug 2016;.

14. Lahfaoui B, Zouggar S, Mohammed B, Elhafyani ML. Real time study of P\&O MPPT control for small wind PMSG turbine systems using Arduino microcontroller. In: 8th International Conference on Sustainability in Energy and Buildings, SEB-16, 11-13 September 2016, Turin, ITALY. vol. 111. Energy Procedia; 2017. p. 1000-1009. 


\title{
Thiết kế bộ điều khiển MPPT cho tuabin gió dùng máy phát đồng bộ nam châm vĩnh cửu
}

\author{
Trương Việt Anh ${ }^{1, *}$, Huỳnh Quang Minh², Võ Hoài Thương ${ }^{3}$
}

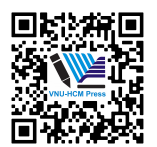

Use your smartphone to scan this QR code and download this article

\section{TÓM TẮT}

Năng lượng gió và các năng lượng tái tạo khác ngày càng được phát triển trên toàn thế giới để thay thế dần năng lượng hóa thạch với tốc độ ngày càng nhanh chóng, đặc biêt tại các nước có tiểm năng gió lớn như Việt Nam. Một đặc điểm của các turbine gió là ứng với mỗi tốc độ gió khác nhau, sẽ tồn tại một điểm làm việc được thể hiện bởi tốc độ quay của turbine gió và moment đầu trục turbine (công suất cơ học) hay dòng điện và điện áp (công suất điện) mà ở đó công suất thu được là lớn nhất. Vi vậy, khi tốc độ gió thay đổi, điểm làm việc này sẽ phải thay đổi để có thể trích xuất được công suất lớn nhất nhẳm nâng cao hiệu suất sử dụng của turbine gió. Việc này, trong một hệ thống turbine gió được giao cho bộ dò tìm công suất cực đại (MPPT) trong hệ thống chuyển đổi năng lượng gió sang năng lượng điện. Trong bài báo này, bộ điều khiển MPPT dựa trên giải thuật nhiễu và quan sát cải tiến được đê xuất cho tuabin gió sử dụng máy phát đồng bộ nam châm vĩnh cửu thu được năng lượng tối đa mà không cần đo tốc độ gió và đặc tuyến công suất của tuabine gió. Mô hình vật lý được thiết kế và thử nghiệm trong điểu kiện phòng thí nghiệm, giải thuật sư dụng $\mathrm{P} \& \mathrm{O}$ cải tiến với 2 hệ số $K_{1}$ và $K_{2}$ được dùng lần lượt khi điểm làm việc ở xa và gần điểm công suất cực đại. Kết quả được mô tả qua một thí nghiệm trên mô hình vật lý, cho phép trích xuất được công suất điện từ turbine gió lớn nhất trong các điều kiện gió thay đổi mà không cần xác định tốc độ gió và đặc tính của hệ thống turbine gió.

Từ khoá: tua bin gió, máy phát đồng bộ nam châm vĩnh cửu, dò tìm điểm công suất cực đại, nhiễu loạn và quan sát, bộ chuyển đổi AC/DC, bộ chuyển đổi DC/DC

\section{${ }^{1}$ Truiờng ĐH Sư phạm Kỹ thuật}

TP.HCM, Viêt Nam

${ }^{2}$ Trường ĐH Bách khoa, ĐHQG-HCM, Việt Nam

${ }^{3}$ Trường CĐ nghề Tiên Giang, Việt Nam

Liên hệ

Trương Việt Anh, Trường ĐH Sư phạm Kỹ thuật TP.HCM, Việt Nam

Email: anhtv@hcmute.edu.vn

Lịch sủ

- Ngày nhận: 08-01-2019

- Ngày chấp nhận: 28-9-2019

- Ngày đăng: 28-12-2019

DOI : 10.32508/stdjet.v2i4.440

\section{Check for updates}

\section{Bản quyền}

๑ Đ ĐHQG Tp.HCM. Đây là bài báo công bố mở được phát hành theo các điều khoản của the Creative Commons Attribution 4.0 International license.

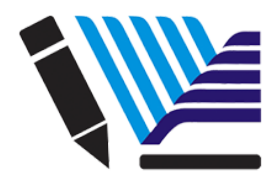

VNU-HCM Press
Trích dẫn bài báo này: Việt Anh $\mathrm{T}$, Quang Minh $\mathrm{H}$, Hoài Thương V. Thiết kế bộ điều khiển MPPT cho tuabin gió dùng máy phát đồng bộ nam châm vĩnh cửu. Sci. Tech. Dev. J. - Eng. Tech.; 2(4):251-257. 